Doi: $10.30868 /$ ad.v4i02.740

\title{
FACTORS THAT ENCOURAGE SMALL AND MEDIUM MICRO ENTERPRISES TO LOAN IN SHARIA BANKING
}

\section{FAKTOR YANG MENDORONG PELAKU USAHA MIKRO KECIL DAN MENENGAH UNTUK MELAKUKAN PEMINJAMAN DI PERBANKAN SYARIAH}

\author{
Alfian Tri Kusuma ${ }^{1}$, Amir Hidayatulloh ${ }^{2}$ \\ Universitas Ahmad Dahlan \\ email: amir.hidayatulloh@act.uad.ac.id
}

\begin{abstract}
The purpose of this study was to analyze the influence of knowledge, motivation, reference groups, and location of banks on the interest of micro, small, and medium enterprises (MSMEs) to lend funds to Islamic Bank. The population in this study is MSMEs in the unique region of Yogyakarta. This study's sample is the MSMEs in the unique region of Yogyakarta who is customers of Islamic Bank. The sampling techniques in this study use convenience sampling. Data collection techniques in this study were carried out by distributing questionnaires and obtained 50 respondents. The data analysis techniques of this study used multiple linear regression analyses with the help of SPSS tools. This study found that of interest of MSMEs to lend fund in Islamic Bank was influenced by knowledge, motivation, reference group, and the location of the bank
\end{abstract}

Keyword: interest; islamic bank; knowledge; motivation; reference group; bank location

\begin{abstract}
ABSTRAK
Tujuan penelitian ini adalah untuk menganalisis pengaruh pengetahuan, motivasi, kelompok acuan, dan lokasi bank terhadap minat pelaku usaha mikro kecil dan menengah (UMKM) untuk melakukan peminjaman dana di perbankan syariah. Populasi dalam penelitian ini adalah pelaku UMKM di Daerah Istimewa Yogyakarta. Sampel dalam penelitian ini adalah pelaku UMKM di Daerah Istimewa Yogyakarta yang menjadi nasabah perbankan syariah. Teknik pengambilan sampel dalam penelitian ini menggunakan convience sampling. Teknik pengumpulan data dalam penelitian ini dilakukan dengan menyebar kuesioner, dan diperoleh 50 responden. Teknik analisis data penelitian ini menggunakan analisis regresi linear berganda dengan bantuan alat SPSS. Penelitian ini memperoleh hasil bahwa minat pelaku UMKM untuk meminjam dana di perbankan syariah dipengaruhi oleh pengetahuan, motivasi, kelompok acuan, serta lokasi bank.
\end{abstract}

Kata kunci: minat; perbankan syariah; pengetahuan; motivasi; kelompok acuan; lokasi bank

\section{A. PENDAhuluan}

Perbankan merupakan salah satu lembaga penyalur dana dari pemilik modal kepada pihak yang memerlukan modal. Perbankan memiliki fungsi strategis guna memajukan pertumbuhan ekonomi pada suatu negara. Perbankan di Indonesia merupakan perbankan yang menerapkan dual banking system, yaitu beroperasi dua jenis bank (bank konvensional dan perbankan syariah). Kehadiran perbankan syariah merupakan salah satu cara yang dilakukan oleh pakar Islam dalam memberikan dukungan ekonomi Islam yang diyakinin mampu menggantikan atau memperbaiki sistem ekonomi konvensional yang berbasis bunga bank. Sedangkan, 
perbankan syariah menerapakan sistem bebas bunga, yaitu menerapakan sistem bagi hasil (Antonio, 2001).

Pendirian lembaga keuangan syariah merupakan hasil kerjasama perbankan Majelis Ulama Indonesia (MUI) sebagaimana berlakunya Undang-undang Nomor 7 Tahun 1992 dan diperbarui dengan Undang-undang Nomor 21 Tahun 2008 tentang perbankan syariah. Sehingga, adanya Undang-undang ini perbankan syariah di Indonesia memiliki landasan hukum yang kuat sehingga secara tidak langsung mendorong pertumbuhan perbankan syariah di Indonesia.

Perkembangan industri perbankan di Indonesia mengalami peningkatan, baik dari sisi kinerja maupun kontribusi. Kinerja perbankan syariah semakin terlihat saat terjadi krisis ekonomi pada pertengahan Juli 1997. Hal ini karena pada krisis ekonomi, perbankan konvensional mengalami keterpurukan akan tetapi perbankan syariah relatif bertahan dan bahkan menunjukan suatu perkembangan. Hal ini karena (1) perbankan syariah beroperasi berdasarkan prinsip syari'ah melalui bagi hasil, sehingga atas dasar bagi hasil, (2) perbankan syariah tidak mengalami negative spread, (3) perbankan syariah bertumpu pada Usaha Mikro, Kecil, dan Menengah (UMKM) yang terbukti tanggu serta dapat bertahan saat terjadi krisis perekonomian global (Muhammad, 2005).

Usaha Mikro Kecil dan Menengah merupakan salah satu yang dapat meningkatkan perekonomian nasional di masa depan, namun perkembangan UMKM seringkali menghadapi persoalan pendanaan. Sehingga, kehadiran lembaga keuangan merupakan salah satu momentum strategis sebagai upaya pembebasan masyarakat pengusaha kecil dari kesulitan meminjam dana dalam mengembangkan usaha ekonominya (Muhammad, 2005).

Kehadiran

lembaga-lembaga

perbankan dan keuangan tersebut hendaknya sudah selayaknya diimbangi dengan peningkatan jumlah entrepreneur. Tumbuhnya etos entreprenurship yang tinggi, khususnya bagi UMKM akan membawa dampak positif pada kemajuan serta kebangkitan ekonomi. Menurut (Walfajri, 2018), Badan Perencanaan Pembangunan Nasional memprediksi jumlah pelaku UMKM di Indonesia pada tahun 2018 sebanyak 58,97 juta orang. Sedangkan, jumlah penduduk Indonesia pada tahun 2018 diprediksi mencapai 265 juta jiwa. Jumlah usaha mikro sebanyak 58,91 unit, usaha kecil 59.260 unit, dan usaha besar 4.987 unit. Sehingga, fenomena ini mengindikasi bahwa UMKM merupakan salah satu usaha produktif yang dapat dikembangkan dengan tujuan untuk mendukung perekonomian, baik secara makro maupun mikro serta dapat memengaruhi sektor-sektor lain yang berkembang, seperti sektor jasa perbankan. Hal ini disebabkan karena hamper sebesar 30 persen usaha UMKM menggunakan modal operasional yang berasal dari pinjaman bank konvensional, lembaga keuangan syariah, maupun menggunakan modal sendiri.

Pertumbuhan ekonomi Daerah Istimewa Yogyakarta pada 2018 diperkirakan berkisar antara 5,2 persen hingga 5,6 persen tiap tahunnya dibandingkan pada 2017 yang mengalami pertumbuhan 5,26 persen. Salah satu faktor yang mendukung perkembangan ekonomi di Daerah Istimewa Yogyakarta adalah pertumbuhan UMKM. Data Bank Indonesia menunjukan bahwa perekonomian Daerah Istimewa Yogyakarta berada pada tren 
positif lebih tinggi diatas perekonomian nasional yakni 5,26 persen. Sementara, perekonomian Indonesia cenderung stabil pada angka 5.07 persen (Kompas.com, 2018).

Menurut (Hidayati, 2013), minat UMKM untuk melakukan peminjaman modal di perbankan syariah dipengaruhi oleh beberapa faktor, seperti pengetahuan, motivasi, kelompok acuan, serta lokasi bank. Pelaku UMKM yang memiliki pengetahuan tentang produk, manfaat, sistem, dan prosedur pada perbankan syariah akan terdorong untuk melakukan peminjaman dana di perbankan syariah.

Pelaku UMKM yang memiliki motivasi agama dan kebutuhan dana juga akan terdorong untuk melakukan peminjaman dana melalui perbankan syariah. Selain itu, keputusan pelaku UMKM untuk melakukan peminjaman dana diperbankan syariah juga dipengaruhi oleh ajakan maupun saran dari kelompok bisnis, orang tua, maupun orang di sekitarnya. Selain itu, lokasi perbankan syariah juga merupakan faktor yang dipertimbangkan pelaku UMKM untuk melakukan peminjaman dana ke perbankan syariah. Sehingga, semakin mudah perbankan terjangkau, semakin aman dan nyaman, serta semakin bersih bank maka mendorong pelaku UMKM untuk melakukan peminjaman dana di perbankan syariah (Hidayati, 2013).

Dari uraian sebelumnya, maka tujuan penelitian ini adalah untuk menganalisis faktor yang mendorong pelaku UMKM untuk meminjam dana di perbankan syariah. Faktor tersebut meliputi pengetahuan, motivasi, kelompok acuan, dan lokasi bank.

\section{B. TINJAUAN PUSTAKA}

1. Peminjaman Dana di Perbankan syariah

Bank didefinisikan sebagai badan usaha yang kegiatannya menghimpun dana dari masyarakat dalam bentuk simpanan dan menyalurkan dana tersebut kepada masyarakat dalam bentuk kredit dana atau bentuk-bentuk lainnya dengan tujuan meningkatkan taraf hidup rakyat banyak. Pembiayaan atau pemodalan berdasarkan prinsip syariah adalah penyediaan uang atau tagihan yang dipersamakan dengan itu serta didasarkan pada persetujuan atau kesepakatan antara pihak perbankan dengan pihak lain yang mewajibkan pihak peminjam untuk melunasi utangnya dengan imbalan bagi hasil (Undang-Undang Republik Indonesia Nomor 10 Tahun 1998).

\section{Usaha Mikro Kecil dan Menengah}

Menurut (Undang-Undang Nomor 20 Tahun 2008), usaha mikro adalah usaha produktif yang dimiliki oleh orang perorangan dan/atau badan usaha perorangan yang memenuhi kriteria usaha mikro. Usaha mikro memiliki kriteria (1) usaha yang memiliki kekayaan bersih paling banyak lima puluh juta rupiah tidak termasuk tanah dan bangunan tempat usaha, serta (2) usaha yang memiliki penjualan tahunan paling banyak tiga ratus juta rupiah.

Usaha kecil merupakan usaha ekonomi produktif yang berdiri sendiri yang dilakukan oleh orang perorangan maupun badan usaha yang bukan merupakan anak perusahaan atau bukan cabang dari perusahaan yang dimiliki, dikuasai, atau menjadi bagian baik secara langsung maupun tidak langsung dari usaha menengah dan usaha besar yang mememuhi usaha kecil. Kriteria usaha kecil meliputi 
(1) usaha yang memiliki kekayaan bersih lebih dari lima puluh juta rupiah sampai dengan lima ratus rupiah tidak termasuk tanah dan bangunan tempat usaha, serta (2) usaha yang memiliki hasil penjualan tahunan lebih dari tiga ratus juta rupiah sampai dengan dua milyar lima ratus rupiah.

Usaha menengah merupakan usaha ekonomi produktif yang berdiri sendiri yang dilakukan oleh orang perseorangan atau badan usaha yang bukan merupakan anak perusahaan atau cabang perusahaan yang dimiliki, dikuasai, atau menjadi bagian baik langsung maupun tidak langsung dengan usaha kecil atau usaha besar yang memenuhi kriteria usaha menengah. Kriteria usaha menengah meliputi (1) usaha yang memiliki kekayaan bersih lebih dari lima ratus juta rupiah sampai dengan sepuluh milyar rupiah tidak termasuk tanah dan bangunan tempat usaha, dan (2) usaha yang memiliki hasil penjualan tahunan lebih dari dua milyar lima ratus juta rupiah sampai dengan paling banyak lima puluh milyar rupiah.

\section{Faktor Pengetahuan}

Pengetahuan adalah segala yang diketahui (Salam, 2008). Sedangkan menurut (Reber, 2010), pengetahuan merupakan kumpulan informasi yang dimiliki oleh individu atau kelompok, maupun budaya tertentu. Secara umum, pengetahuan memiliki beberapa indikator yang dapat memengaruhi pengetahuan individu antara lain umur, pendidikan, pekerjaan, pengalaman, sumber informasi (Notoatmodjo, 2003).

\section{Faktor Motivasi}

Motivasi merupakan suatu proses memengaruhi individu atau kelompok kerja agar individu dan kelompok kerja tersebut berkeinginan untuk melaksanakan sesuatu yang telah ditetapkan. Motivasi biasanya berupa dorongan dari luar individu (Samsudin, 2010). Hal senada juga diungkapkan oleh Liang Gie dalam (Samsudin, 2010), motivasi adalah pekerjaan yang dilakukan oleh manajer dengan cara memberikan inspirasi, semangat, maupun dorongan kepada karyawan untuk mengambil sebuah tindakan tertentu.

\section{Faktor Kelompok Acuan}

Kelompok acuan merupakan individu maupun suatu kelompok individu yang memengaruhi perilaku individu lain. Kelompok acuan memberikan suatu norma serta nilai yang dapat menentukan perspektif tertentu yang terkait dengan cara berpikir atau berperilaku. Kelompok acuan meliputi pengaruh perorangan maupun kelompok baik secara langsung maupun tidak langsung, seperti keluarga, teman akrab dan sebagainya (Engel, Blackwell, \& Miniard, 1994).

Theory of Planned Behavior menyatakan bahwa salah satu faktor yang mendorong perilaku individu adalah norma subjektif. Norma subjektif mengarah pada suatu tekanan yang dipersepsikan untuk melakukan atau tidak melakukan suatu perbuatan (Ajzen \& Fishbein, 1980); (Ajzen, 1991). Sehingga, individu akan berperilaku dengan mempertimbangkan kepercayaan-kepercayaan orang lain, misalnya keluarga, teman, atasan, dan lain sebagainya. Menurut (Engel et al., 1994), indikator yang menunjukan kapabilitas dari kelompok acuan meliputi (1) pengetahuan kelompok acuan mengenai produk, (2) kredibilitas dari kelompok acuan, (3) pengalaman dari kelompok acuan, (4) keaktifan kelompok acuan, dan (5) daya tarik kelompok acuan. 


\section{Faktor Lokasi}

Lokasi merupakan pendorong biaya dan pendapatan, sehingga lokasi seringkali menjadi salah satu faktor penentu dalam membuat strategi bisnis. Lokasi merupakan salah satu cara untuk memaksimalkan keuntungan (Heizer \& Render, 2015). Bahkan (Kotler, 2008) mengatakan bahwa salah satu kunci sukses bisnis adalah lokasi yang dimulai dengan pemilihan komunitas.

Perencanaan yang baik merupakan langkah awal dari pendirian perusahaan, termasuk didalamnya pemilihan lokasi. Hal ini karena lokasi akan memengaruhi biaya operasi/produksi, harga jual, serta kemampuan perusahaan untuk bersaing di pasar (Subagyo, 2000). Bahkan (Lupiyoadi \& Hamdani, 2009) mengatakan bahwa lokasi berhubungan dengan dimana perusahaan harus bertempat guna melakukan aktivitas operasinya.

\section{HIPOTESIS}

1. Pengaruh Pengetahuan Terhadap Niat Pelaku UMKM untuk Meminjam Dana di Perbankan syariah

Menurut (Reber, 2010), pengetahuan adalah kumpulan informasi yang dimiliki oleh individu, kelompok maupun budaya tertentu. Menurut (Hidayati, 2013), salah satu faktor yang memengaruhi pengusaha muslim untuk melakukan pembiayaan pada perbankan syariah adalah faktor pengetahuan. Oleh karena itu, pelaku UMKM yang memiliki pengetahuan lebih mengenai produk, manfaat, sistem, dan prosedur pada perbankan syariah, maka pelaku UMKM tersebut akan terdorong untuk melakukan peminjaman dana di perbankan syariah. Hasil penelitian yang serupa diperoleh (Saputra, Kusumaningtyas, \& Alfiani, 2018); (Banowati, 2018); (Adawiyah, 2015); (Hidayati, 2013) yang menyatakan bahwa pemahaman prinsip dari perbankan syariah dapat mendorong minat nasabah untuk melakukan peminjaman dana di perbankan syariah. Oleh karena itu, hipotesis pertama $\left(\mathrm{H}_{1}\right)$ penelitian ini adalah sebagai berikut.

$\mathrm{H}_{1}$ : pengetahuan berpengaruh terhadap minat untuk meminjam dana di perbankan syariah

\section{Pengaruh Motivasi Terhadap Niat UMKM untuk Meminjam Dana di Perbankan syariah}

Menurut (Samsudin, 2010), motivasi merupakan proses memengaruhi atau mendorong individu atau kelompok kerja yang berasal dari luar agar dapat melaksanakan sesuatu sesuai dengan ketetapan. Berdasarkan penelitian (Hidayati, 2013) menunjukan bahwa faktor motivasi memengaruhi keputusan pengusaha muslim melakukan pembiayaan di perbankan syariah. Pelaku UMKM termotivasi dengan adanya dorongan agama dan kebutuhan untuk meminjam dana di perbankan syariah. Selain itu, motivasi nasabah melakukan peminjaman di perbankan syariah menurut (Adawiyah, 2015) karena pertimbangan laba atau rugi yang akan diperoleh dari tawaran pihak perbankan syariah. Oleh karena itu, hipotesis kedua $\left(\mathrm{H}_{2}\right)$ penelitian ini adalah sebagai berikut.

$\mathrm{H}_{2}$ : motivasi berpengaruh terhadap minat untuk meminjam dana di bank syariah

\section{Pengaruh Kelompok Acuan Terhadap Niat UMKM untuk Meminjam Dana di Perbankan syariah}

Kelompok acuan adalah orang atau sekelompok orang yang memengaruhi perilaku individu. Kelompok acuan memberikan standar (norma) dan nilai yang dapat menjadi perspektif penentu yang terkait dengan bagaimana seseorang berpikir atau berperilaku. Kelompok acuan meliputi pengaruh perorangan atau kelompok baik secara langsung maupun 
tidak langsung, seperti keluarga, teman dan lain sebagainya (Engel et al., 1994). Menurut (Awan \& Azhar, 2014); (Hidayati, 2013), faktor kelompok acuan merupakan salah satu faktor yang mememengaruhi keputusan pengusaha muslim melakukan peminjaman di perbankan syariah. Sehingga, semakin sering ajakan/saran kelompok bisnis dan orang tua dalam meminjam di perbankan syariah maka semakin besar pelaku UMKM untuk meminjam dana di perbankan syariah. Oleh karena itu, hipotesis ketiga $\left(\mathrm{H}_{3}\right)$ penelitian ini adalah sebagai berikut.

$\mathrm{H}_{3}$ : kelompok acuan berpengaruh terhadap minat UMKM untuk meminjam dana di perbankan syariah

\section{Pengaruh Lokasi Bank Terhadap Niat UMKM untuk Meminjam Dana di Perbankan syariah}

Menurut (Heizer \& Render, 2015), lokasi merupakan pendorong biaya dan pendapatan. Sehingga, lokasi seringkali memiliki kekuasaan dalam pembuatan strategi bisnis perusahaan. Lokasi yang strategis bertujuan untuk memaksimalkan keuntungan dari lokasi perusahaan. Menurut (Saputra et al., 2018); (Adawiyah, 2015); (Hidayati, 2013), faktor lokasi bank memengaruhi keputusan pengusaha muslim untuk melakukan peminjaman dana di perbankan syariah. Sehingga, semakin mudah bank dijangkau, semakin aman dan nyaman, serta semakin bersih sebuah perbankan syariah maka mendorong UMKM untuk melakukan peminjaman dana di bank syriah. Oleh karena itu, hipotesis keempat $\left(\mathrm{H}_{4}\right)$ penelitian ini adalah sebagai berikut.

$\mathrm{H}_{4}$ : lokasi bank berpengaruh terhadp minat UMKM untuk meminjam dana di perbankan syariah

Dari uraian kajian pustaka dan pengembangan hipotesis, maka rerangka penelitian ini adalah sebagai berikut.

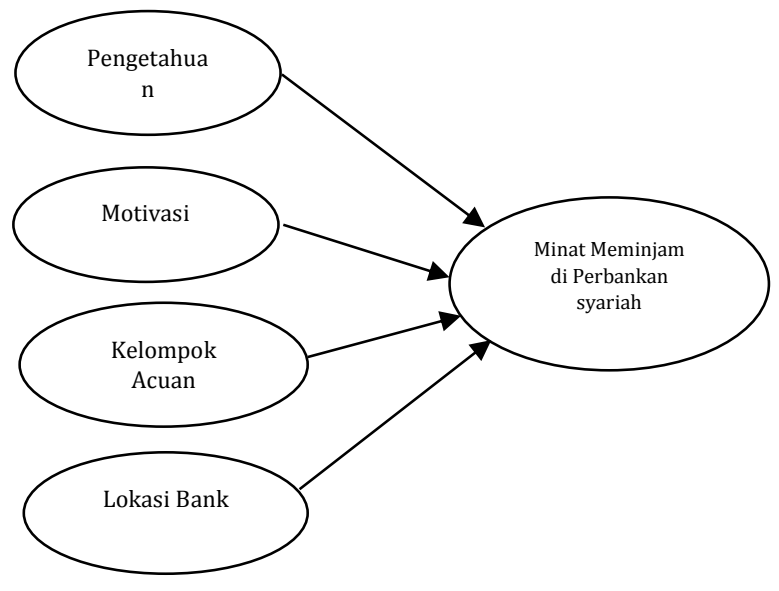

Gambar 1. Rerangka Penelitian

\section{METODE PENELITIAN}

Populasi dalam penelitian ini adalah pelaku usaha mikro kecil dan menengah di Daerah Istimewa Yogyakarta. Sampel dalam penelitian ini adalah pelaku usaha mikro kecil dan menengah di Daerah Istimewa Yogyakarta yang menjadi nasabah perbankan syariah. Teknik pengambilan sampel dalam penelitian menggunakan convience sampling. Variabel dalam penelitian ini terdiri dari variabel independen (pengetahuan, motivasi, kelompok acuan, dan lokasi bank) dan variabel dependen (minat meminjam di perbankan syariah. Definisi operasional dan pengukuran variabel disajikan pada tabel 1. Pengumpulan data dalam penelitian ini dilakukan dengan melakukan penyebaran kuesioner. Teknik analisis data dalam penelitian ini menggunakan analisis regresi linear berganda. 


\begin{tabular}{|c|c|c|c|c|}
\hline $\begin{array}{l}\text { Varia } \\
\text { bel }\end{array}$ & $\begin{array}{l}\text { Defini } \\
\text { si }\end{array}$ & $\begin{array}{l}\text { Refe } \\
\text { rensi }\end{array}$ & $\begin{array}{l}\text { Pengu } \\
\text { kuran }\end{array}$ & $\begin{array}{l}\text { Refe } \\
\text { rens } \\
\text { i }\end{array}$ \\
\hline Minat & $\begin{array}{l}\text { Keingi } \\
\text { nan } \\
\text { pada } \\
\text { suatu } \\
\text { objek } \\
\text { akan } \\
\text { lebih } \\
\text { kelihat } \\
\text { an } \\
\text { apabil } \\
\text { a } \\
\text { objek } \\
\text { terseb } \\
\text { ut } \\
\text { sesuai } \\
\text { denga } \\
\mathrm{n} \\
\text { sasara } \\
\mathrm{n} \text { yang } \\
\text { berkait } \\
\text { an } \\
\text { denga } \\
\mathrm{n} \\
\text { kebutu } \\
\text { han } \\
\text { indivi } \\
\text { du } \\
\text { terseb } \\
\text { ut }\end{array}$ & $\begin{array}{l}\text { (Sudi } \\
\text { rman, } \\
2013 \\
\text { ) }\end{array}$ & $\begin{array}{l}\text { Lima } \\
\text { item } \\
\text { pertan } \\
\text { yaan } \\
\text { denga } \\
\mathrm{n} \\
\text { mengg } \\
\text { unaka } \\
\text { n skala } \\
\text { likert } \\
\text { lima } \\
\text { poin }\end{array}$ & $\begin{array}{l}\text { (Hid } \\
\text { ayati } \\
\text { 2013 } \\
\text { ) }\end{array}$ \\
\hline $\begin{array}{l}\text { Penge } \\
\text { tahua } \\
\text { n }\end{array}$ & $\begin{array}{l}\text { Kump } \\
\text { ulan } \\
\text { inform } \\
\text { asi } \\
\text { yang } \\
\text { dimili } \\
\text { ki oleh } \\
\text { indivi } \\
\text { du, } \\
\text { kelom } \\
\text { pok, } \\
\text { maupu } \\
\text { n } \\
\text { buday } \\
\text { a }\end{array}$ & $\begin{array}{l}\text { (Sala } \\
\text { m, } \\
2008 \\
\text { ) }\end{array}$ & $\begin{array}{l}\text { Empat } \\
\text { item } \\
\text { pertan } \\
\text { yaan } \\
\text { denga } \\
\mathrm{n} \\
\text { mengg } \\
\text { unaka } \\
\text { n skala } \\
\text { likert } \\
\text { lima } \\
\text { poin }\end{array}$ & $\begin{array}{l}(\mathrm{Hid} \\
\text { ayati } \\
{ }^{2} \\
)\end{array}$ \\
\hline
\end{tabular}

\begin{tabular}{|c|c|c|c|c|}
\hline & $\begin{array}{l}\text { tertent } \\
\mathrm{u}\end{array}$ & & & \\
\hline $\begin{array}{l}\text { Motiv } \\
\text { asi }\end{array}$ & $\begin{array}{l}\text { Proses } \\
\text { meme } \\
\text { ngaruh } \\
\text { i atau } \\
\text { mendo } \\
\text { rong } \\
\text { dari } \\
\text { luar } \\
\text { terhad } \\
\text { ap } \\
\text { indivi } \\
\text { du } \\
\text { atau } \\
\text { kelom } \\
\text { pok } \\
\text { kerja } \\
\text { agar } \\
\text { mau } \\
\text { melak } \\
\text { ukan } \\
\text { sesuat } \\
\text { u yang } \\
\text { telah } \\
\text { ditetap } \\
\text { kan }\end{array}$ & $\begin{array}{l}\text { (Sam } \\
\text { sudin } \\
\text { 2010 } \\
\text { ) }\end{array}$ & $\begin{array}{l}\text { Dua } \\
\text { item } \\
\text { pertan } \\
\text { yaan } \\
\text { denga } \\
\text { n } \\
\text { mengg } \\
\text { unaka } \\
\text { n skala } \\
\text { likert } \\
\text { lima } \\
\text { poin }\end{array}$ & $\begin{array}{l}\text { (Hid } \\
\text { ayati } \\
2013 \\
\text { ) }\end{array}$ \\
\hline $\begin{array}{l}\text { Kelom } \\
\text { pok } \\
\text { acuan }\end{array}$ & $\begin{array}{l}\text { Orang } \\
\text { atau } \\
\text { kelom } \\
\text { pok } \\
\text { orang } \\
\text { yang } \\
\text { meme } \\
\text { ngaruh } \\
\text { i } \\
\text { perilak } \\
\text { u } \\
\text { indivi } \\
\text { du }\end{array}$ & $\begin{array}{l}\text { (Eng } \\
\text { el et } \\
\text { al., } \\
1994 \\
\text { ) }\end{array}$ & $\begin{array}{l}\text { Dua } \\
\text { item } \\
\text { pertan } \\
\text { yaan } \\
\text { denga } \\
\text { n } \\
\text { mengg } \\
\text { unaka } \\
\text { n skala } \\
\text { likert } \\
\text { lima } \\
\text { poin }\end{array}$ & $\begin{array}{l}\text { (Hid } \\
\text { ayati } \\
\text { 2013 } \\
\text { ) }\end{array}$ \\
\hline $\begin{array}{l}\text { Lokas } \\
\text { i bank }\end{array}$ & $\begin{array}{l}\text { Pendo } \\
\text { rong } \\
\text { biaya } \\
\text { dan } \\
\text { penda } \\
\text { patan }\end{array}$ & $\begin{array}{l}\text { (Heiz } \\
\text { er \& } \\
\text { Rend } \\
\text { er, } \\
2015 \\
\text { ) }\end{array}$ & $\begin{array}{l}\text { Empat } \\
\text { item } \\
\text { pertan } \\
\text { yaan } \\
\text { denga } \\
\mathrm{n} \\
\text { mengg } \\
\text { unaka } \\
\mathrm{n} \text { skala }\end{array}$ & $\begin{array}{l}\text { (Hid } \\
\text { ayati } \\
2013 \\
\text { ) }\end{array}$ \\
\hline
\end{tabular}




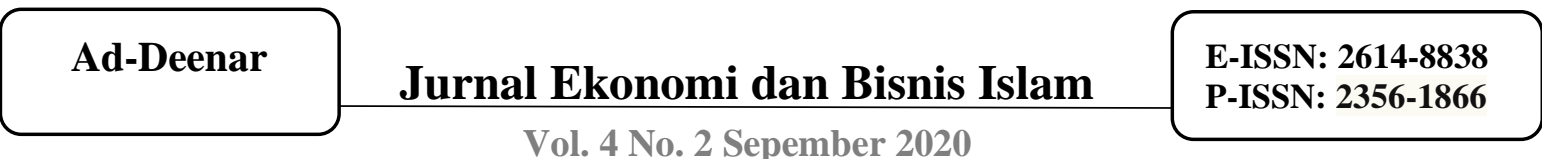

Vol. 4 No. 2 Sepember 2020

\begin{tabular}{ll}
\hline likert \\
lima \\
poin \\
\hline
\end{tabular}

\section{E. PEMBAHASAN}

Responden dalam penelitian berjumlah 50 responden. Responden dalam penelitian ini didominasi oleh responden berjenis kelamin perempuan (33 responden) dan 17 responden berjenis kelamin laki-laki. Usia responden didominasi oleh usia lebih dari 40 tahun (33 responden), sedang responden yang memiliki usia dibawah 40 tahun adalah 17 responden. Tingkat pendidikan responden didominasi oleh tingkat pendidikan SMP (24 responden) responden, sedangkan responden yang memiliki tingkat pendidikan SMA (21 responden), dan lima responden memiliki tingkat pendidikan sarjana.

Pengujian hipotesis dalam penelitian ini menggunakan analisis regresi linear berganda dengan bantuan alat SPSS. Sehingga sebelum melakukan pengujian hipotesis, penelitian ini terlebih dahulu melakukan uji kualitas data (uji validitas dan uji reliabilitas) serta uji asumsi klasik (uji normalitas, uji heteroskesdastisitas, serta uji multikolinieritas). Penelitian ini memenuhi uji kualitas data dan uji asumsi klasik. Oleh karena itu, tahap selanjutnya adalah pengujian hipotesis. Hasil pengujian hipotesis disajikan pada tabel 2.
Tabel 2. Hasil Pengujian Hipotesis

\begin{tabular}{|c|c|c|c|c|}
\hline $\begin{array}{c}\text { Variabe } \\
l\end{array}$ & $\begin{array}{c}\text { Koefe } \\
\text { sien }\end{array}$ & $\begin{array}{l}\text { Sig } \\
(2- \\
\text { tail } \\
\text { ed })\end{array}$ & $\begin{array}{c}\text { Alp } \\
h a\end{array}$ & $\begin{array}{c}\text { Keput } \\
\text { usan }\end{array}$ \\
\hline $\begin{array}{l}\text { Pengeta } \\
\text { huan }\end{array}$ & 0,335 & $\begin{array}{c}0,04 \\
4\end{array}$ & $\begin{array}{c}0,0 \\
5\end{array}$ & $\begin{array}{c}\mathrm{H}_{1} \\
\text { Terduk } \\
\text { ung }\end{array}$ \\
\hline $\begin{array}{l}\text { Motivas } \\
\text { i }\end{array}$ & 0,489 & $\begin{array}{c}0,04 \\
6\end{array}$ & $\begin{array}{c}0,0 \\
5\end{array}$ & $\begin{array}{c}\mathrm{H}_{1} \\
\text { Terduk } \\
\text { ung }\end{array}$ \\
\hline $\begin{array}{l}\text { Kelomp } \\
\text { ok } \\
\text { Acuan }\end{array}$ & 0,738 & $\begin{array}{c}0,00 \\
1\end{array}$ & $\begin{array}{c}0,0 \\
5\end{array}$ & $\begin{array}{c}\mathrm{H}_{1} \\
\text { Terduk } \\
\text { ung }\end{array}$ \\
\hline $\begin{array}{l}\text { Lokasi } \\
\text { Bank }\end{array}$ & 0,514 & $\begin{array}{c}0,00 \\
3\end{array}$ & $\begin{array}{c}0,0 \\
5\end{array}$ & $\begin{array}{c}\mathrm{H}_{1} \\
\text { Terduk } \\
\text { ung }\end{array}$ \\
\hline $\begin{array}{l}\text { Konstanta } \\
\text { Variabel I } \\
\text { Peminjam } \\
\text { syariah } \\
\text { Adjusted } \\
\text { F Statistik } \\
\text { Signifikan }\end{array}$ & $\begin{array}{l}\text { Depende } \\
\text { an Dan }\end{array}$ & \multicolumn{3}{|c|}{$\begin{array}{l}\quad=\mathbf{- 3 , 7 2 3} \\
=\text { Minat } \\
\text { di Perbankan }\end{array}$} \\
\hline
\end{tabular}

Sumber: data primer, diolah (2019)

Tabel 2 menunjukan bahwa penelitian ini memiliki nilai adjusted $R$-square sebesar 0,737 . Hal ini berarti variabel dependen (niat pelaku UMKM untuk meminjam dana di perbankan syariah) dapat dijelaskan oleh variabel independen (pengetahuan, motivasi, kelompok acuan, dan lokasi bank) sebesar 73,7 persen dan 26,3 persen dijelaskan oleh variabel indepeden lain di luar modal.

Tabel 2 juga menunjukan hasil uji $\mathrm{F}$. Hasil uji $F$ menunjukan nilai signifikasi $(0,000)$ yang lebih kecil dibandingkan dengan 0,05. Sehingga, minimal ada satu variabel independen (pengetahuan, motivasi, kelompok acuan, dan lokasi bank) 
yang berpengaruh terhadap niat pelaku UMKM untuk meminjam dana di perbankan syariah.

Minat pelaku UMKM untuk meminjam dana di perbankan syariah dipengaruhi oleh pengetahuan, motivasi, kelompok acuan, dan lokasi usaha. Hal ini karena variabel pengetahuan (signifikasi 0,044), motivasi (signifikasi 0,046), kelompok acuan (signifikasi 0,001) dan lokasi bank (signifikasi 0,003) yang lebih kecil dari 0,05 . Atau dengan kata lain, hipotesis pertama $\left(\mathrm{H}_{1}\right)$, hipotesis kedua $\left(\mathrm{H}_{2}\right)$, hipotesis ketiga $\left(\mathrm{H}_{3}\right)$, dan hipotesis keempat $\left(\mathrm{H}_{4}\right)$ penelitian ini terdukung.

Pelaku UMKM yang memiliki pengetahuan lebih mengenai produk, manfaat, sistem, serta prosedur dari perbankan syariah, maka pelaku UMKM tersebut akan terdorong untuk melakukan peminjaman dana di perbankan syariah. Hasil penelitian ini mendukung hasil penelitian sebelumnya (Saputra et al., 2018); (Banowati, 2018); (Adawiyah, 2015); (Hidayati, 2013) yang menyatakan bahwa pengetahuan berpengaruh terhadap minat individu untuk melakukan peminjaman dana di perbankan syariah. Oleh karena itu, pihak perbankan syariah diharapkan dapat melakukan sosialisasi mengenai perbankan syariah kepada masyarakat, khususnya para pelaku UMKM dengan tujuan agar nasabah perbankan syariah bertambah banyak.

Faktor lain yang mendorong pelaku UMKM untuk melakukan peminjaman dana di perbankan syariah adalah faktor motivasi. Sehingga, pelaku UMKM melakukan peminjaman dana di perbankan syariah salah satunya karena adanya perintah/dorongan dari agama yang dianutnya. Hasil penelitian ini mendukung hasil penelitian sebelumnya (Hidayati,
2013) yang menyatakan bahwa motivasi memengaruhi minat individu untuk melakukan peminjaman dana di perbankan syariah. Hal ini karena perbankan syariah menerapkan prinsip bagi hasil, bukan riba. Hal ini karena riba menurut ajaran islam adalah haram. Keharaman riba dijelaskan pada (Qs. Ali Imron (3): 130) yang artinya "Hai orang-orang yang beriman, janganlah kamu memakan riba dengan berlipat ganda dan bertakwalah kamu kepada Allah supaya kamu mendapat keberuntungan. Peliharalah dirimu dari api neraka, yang disediakan untuk orang-orang yang kafir".

Saran atau ajakan dari kelompok acuan merupakan salah satu faktor yang mendorong minat individu untuk melakukan peminjaman dana di perbankan syariah. Sehingga, semakin sering kelompok acuan memberi saran atau mengajak, maka pelaku UMKM semakin terdorong untuk melakukan peminjaman dana di perbankan syariah. Kelompok acuan meliputi rekan kerja, orang tua, teman, dan lain sebagainya. Hasil penelitian ini mendukung hasil penelitian sebelumnya (Awan \& Azhar, 2014); (Hidayati, 2013) yang menyatakan bahwa salah satu faktor yang mendorong individu untuk melakukan peminjaman di perbankan syariah adalah peran dari kelompok acuan.

Faktor lain yang berperan dalam mendorong pelaku UMKM untuk melakukan peminjaman dana di perbankan syariah adalah faktor lokasi bank. Sehingga, semakin mudah perbankan bank dijangkau, semakin aman dan nyaman, serta semakin bersih perbankan maka pelaku UMKM akan lebih terdorong untuk melakukan peminjaman di perbankan syariah. Sehingga, pihak perbankan syariah diharapkan dapat menjaga rasa aman dan 


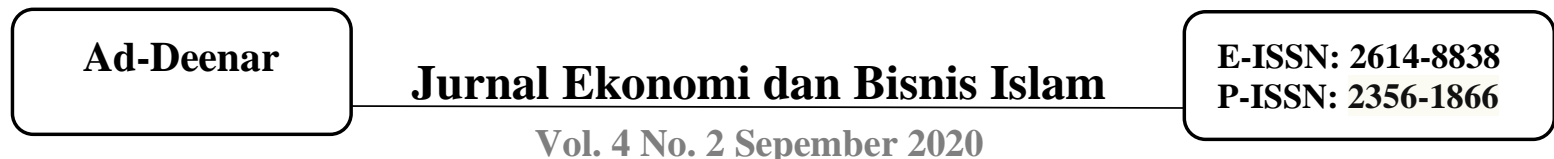

nyaman nasabah, serta menjaga kebersihan agar nasabahnya bertambah. Hasil penelitian ini mendukung hasil penelitian sebelumnya Menurut (Saputra et al., 2018); (Adawiyah, 2015); (Hidayati, 2013) yang menyatakan bahwa lokasi bank berpengaruh terhadap minat individu untuk melakukan peminjaman dana di perbankan syariah.

\section{F. KESIMPULAN}

Pelaku usaha mikro kecil dan menengah untuk melakukan peminjaman dana di perbankan syariah dipengaruhi oleh beberapa faktor. Faktor tersebut meliputi pengetahuan yang dimiliki oleh pelaku UMKM mengenai perbankan syariah, motivasi yang berasal dari dorongan ajaran agamanya, kelompok acuan, serta lokasi perbankan syariah.

Responden dalam penelitian ini relatif sedikit. Hal ini karena beberapa responden enggan untuk mengisi kuesioner. Sehingga, penelitian selanjutnya diharapkan dapat menambah jumlah responden.

\section{DAFTAR PUSTAKA}

Adawiyah, W. R. (2015). Pertimbangan, Pengetahuan, Dan Sikap Konsumen Individu Terhadap Bank Syariah. Jurnal Ekonomi Pembangunan: Kajian Masalah Ekonomi Dan Pembangunan, 11(2), 191. https://doi.org/10.23917/jep.v11i2.32 4

Ajzen, I. (1991). The Theory of Planned Behavior. Organizational Behavior and Human Decision Process, 50, 179-211.

Ajzen, I., \& Fishbein, M. (1980). Understanding Attitudes and Predicting Social Behavior. Englewood Cliffs: Prentice Hall.

Antonio, M. S. (2001). Bank Syariah dari
Teori ke Praktik. Jakarta: Gema Insani Press.

Awan, A. G., \& Azhar, M. (2014). Consumer Behaviour Towards Islamic Banking In Pakistan. European Journal of Accounting Auditing and Finance Research, 2(9), 42-65.

Banowati, M. M. (2018). Pengaruh Pemahaman Prinsip Tabungan Syariah, Tingkat Religiusitas, Faktor Sosial Budaya, dan Persepsi Tentang Bank Syariah Terhadap Niat Menabung di Bank Syariah Pada Mahasiswa Pendidikan Ekonomi Angkatan Tahun 2014 Universitas Negeri Yogyakarta. Universitas Negeri Yogyakarta.

Engel, J. F., Blackwell, G., \& Miniard, P. W. (1994). Perilaku Konsumen. Jakarta: Binarupa Aksara.

Heizer, J., \& Render, B. (2015). Operations Management (Manajemen Operasi). Jakarta: Salemba Empat.

Hidayati, N. A. (2013). Analisis Keputusan Pengusaha Muslim dalam Melakukan Pembiyaan Pada Bank Syariah di Tulungagung. Jurnal Dinamika, 13(7).

Kompas.com. (2018). BI: Pertumbuhan Ekonomi DIY hingga 5,6 Persen di 2018 - Kompas.com. Retrieved from https://regional.kompas.com/read/201 8/05/08/11093651/bi-pertumbuhanekonomi-diy-hingga-56-persen-di2018

Kotler, P. (2008). Prinsip - prinsip Pemasaran. Jakarta: Erlangga.

Lupiyoadi, \& Hamdani. (2009). Manajemen Pemasaran Jasa. Jakarta: Salemba Empat.

Muhammad. (2005). Bank Syariah: Problem dan Prospek Perkembangan di Indonesia. Yogyakarta: Graha Ilmu.

Notoatmodjo, S. (2003). Pendidikan dan Perilaku Kesehatan. Jakarta: Rineka Cipta. 
Reber. (2010). Kamus Psikologi. Yogyakarta: Pustaka Pelajar.

Salam, B. (2008). Pengantar Filsafat. Jakarta: Bumi Aksara.

Samsudin, S. (2010). Manajemen Sumber Daya Manusia. Bandung: Pustaka Setia.

Saputra, A., Kusumaningtyas, R., \& Alfiani, N. (2018). Identifikasi Faktor Penentu Keputusan Konsumen Dalam Memilih Produk Perbankan (Studi Kasus $\square$ : Mahasiswa UIN Syarif Hidayatullah Jakarta). Studia Informatika: Jurnal Sistem Informasi, 10(1), 21-28.

Subagyo, P. (2000). Manajemen Operasi. Jakarta: Bumi Aksara.
Sudirman. (2013). Pembentukan Minat. Jakarta: Pustaka Karya.

Undang-Undang Nomor 20 Tahun 2008 Tentang Usaha Mikro Kecil dan Menengah

Undang-Undang Republik Indonesia Nomor 10 Tahun 1998 Tentang Perbankan. Retrieved from https://www.bphn.go.id/data/documen ts/98uu010.pdf

Walfajri, M. (2018). Jumlah pelaku UMKM di 2018 diprediksi mencapai 58,97 juta orang. Retrieved from https://keuangan.kontan.co.id/news/ju mlah-pelaku-umkm-di-2018diprediksi-mencapai-5897-juta-orang 
